\title{
HABITAT AND BIOLOGICAL CHARACTERISTIC OF TILAPIA (Oreochromis niloticus) IN BATUR LAKE
}

\section{KARAKTERISTIK HABITAT DAN BIOLOGI}

\section{IKAN NILA (Oreochromis niloticus) di Danau Batur}

\author{
Ni Komang Suryati \& Samuel \\ Balai Penelitian Perikanan Perairan Umum Jalan Beringin No. 08 Mariana Palembang \\ Email:komang_nks@yahoo.com
}

\begin{tabular}{|c|c|}
\hline INFO ARTIKEL & A B S T R A C T \\
\hline $\begin{array}{l}\text { Diterima: } 2 \text { September } 2018 \\
\text { Disetujui: } 26 \text { Oktober } 2018\end{array}$ & Study on habitat and biological characteristic of Tilapia (Oreochromis \\
\hline $\begin{array}{l}\text { Kata kunci: } \\
\text { Tilapia (Oreochromis } \\
\text { niloticus), Batur Lake }\end{array}$ & $\begin{array}{l}\text { November 2011. The result investigations of water quality } \\
\text { parameters at six research station showed that support for the life of } \\
\text { Tilapia. Exploitation rate of Tilapia was exceed the optimum rate } \\
\text { (over fishing). Tilapia in Batur lake was able to reach } 41,45 \mathrm{~cm} \text { on } \\
\text { size with growth rate (K) } 0,52 \text { per year. Tilapia in Batur lake was } \\
\text { spawn throughout the year (IKG }<20 \% \text { ) with the top of spawning on } \\
\text { March and July. The size of first maturity was } 17,559-20,408 \mathrm{~cm} \text {. } \\
\text { Tilapia in Batur Lake was herbivore to omnivore as the first consumer } \\
\text { level with generalis pattern. }\end{array}$ \\
\hline
\end{tabular}

\section{PENDAHULUAN}

Ikan nila (Oreochromis niloticus) merupakan spesies yang berasal dari kawasan Sungai Nil dan danau-danau sekitarnya di Afrika. Ikan Nila memiliki bentuk tubuh yang pipih ke arah vertikal (kompres) dengan profil empat persegi panjang ke arah antero posterior. Posisi mulut terletak di ujung hidung (terminal) dan dapat disembuhkan. Pada sirip ekor tampak jelas garis-garis vertikal dan pada sirip punggungnya garis tersebut kelihatan condong letaknya. Ciri khas ikan nila adalah garis-garis vertikal berwarna hitam pada sirip ekor, punggung dan dubur. Pada bagian sirip caudal (ekor) dengan bentuk membulat. Pada rahang terdapat bercak kehitaman. Sisik ikan nila adalah tipe ctenoid. Ikan nila juga ditandai dengan jari-jari dorsal yang keras, begitu pun bagian analnya. Dengan posisi sirip anal di belakang sirip dada (abdominal).

Danau Batur merupakan salah satu tipe danau vulkanik, terletak dikaki Gunung Batur yang diyakini merupakan sebuah kaldera (kawah gunung berapi) purba. Berdasarkan Suryono et al. (2008), Danau Batur terletak di Kabupaten Bangli pada ketinggian 1080 m dpl, luas 16,05 $\mathrm{km}^{2}$ dengan kedalaman maksimal $60 \mathrm{~m}$. Berdasarkan informasi dari masyarakat setempat (komunikasi pribadi) ikan nila di introduksikan ke Danau Batur sejak 30 tahun yang lalu. Ikan Nila merupakan salah satu jenis ikan ekonomis penting dengan harga berkisar antara Rp 18.000,hingga Rp 20.000,- / kg. Ikan ini juga dominan berkembang biak di Danau Batur. Aktifitas penangkapan ikan oleh nelayan di Danau Batur banyak dilakukan dengan menggunakan berbagai macam alat tangkap seperti jaring insang (gill net), pancing (hook and line), serta angas (barrier trap). Untuk mendukung kelestarian ikan Nila di Danau Batur maka perlu adanya data 
dan informasi mengenai karakteristik habitat dan aspek biologinya. Penelitian ini bertujuan untuk mengetahui karakteristik habitat serta beberapa aspek biologi Ikan Nila di Danau Batur.

\section{METODE PENELITIAN}

Penelitian ini dilakukan di Danau Batur Kabupaten Bangli Propinsi Bali ( Gambar 1) pada tahun 2011 dengan menggunakan metode penelitian survey dan pengamatan di Laboratorium Hidrobiologi dan Kimia Balai Penelitian Perikanan Perairan Umum. Stasiun pengambilan contoh ditentukan secara purposive random sampling. Beberapa paramater lingkungan yang diamati meliputi suhu, Dissolved Solid (TDS), Daya Hantar Listrik (DHL), kedalaman air, kecerahan, oksigen terıarut, $\mathrm{pH}$, alkalinitas, $\mathrm{CO} 2$ bebas, dan klorofil-a. Metode pengukuran dan analisis serta alat yang digunakan berpedoman pada buku American Public Health Association (1981) dan Boyd (1988).

Contoh ikan dikumpulkan dari hasil tangkapan nelayan dan selanjutnya ikan diawetkan dengan menggunakan formalin $10 \%$. Jumlah ikan contoh yang dianalisa untuk parameter pertumbuhannya sebanyak 443 ekor sedangkan untuk analisa isi saluran pencernaan hanya dilakukan pada 35 ekor ikan.

Selanjutnya sampel ikan dianalisis di Laboratorium Hidrobiologi Balai Penelitian Perikanan Perairan Umum (BPPPU). Parameter populasi ikan Nila di hitung dengan menggunakan program FISAT. Karakteristik habitat ikan nila di analisis dengan menggunakan Principal Component dan Classification Analysis dengan program Statistica 8. Parameter biologi yang diamati meliputi Indeks Kematangan Gonad, ukuran pertama matang gonad, fekunditas, diameter telur serta kebiasaan makan.

Pembedahan dilakukan untuk melihat gonad serta isi saluran pencernaan. Pengukuran berat gonad menggunakan timbangan digital sartorius dengan ketelitian 0,01 gram serta panjang saluran pencernaan menggunakan penggaris baja dengan ketelitian $1 \mathrm{~mm}$, kemudian isinya dianalisa. TKG diamati secara visual dengan cara membedah perut ikan dan dilihat tingkat perkembangan gonadnya berdasarkan modifikasi dari Cassie (Effendie, 1979). Indeks Kematangan Gonad (IKG) dihitung dengan cara mengukur bobot gonad dan bobot tubuh ikan termasuk gonad menggunakan timbangan yang mempunyai ketelitian 0,01 gram. Gonad ditimbang dari masing-masing TKG. Nilai IKG dianalisis menggunakan rumus Effendie (1979) yaitu :

$I K G=\frac{B G}{B T} \times 100 \%$

dimana :

$\mathrm{BG}=$ bobot $\operatorname{gonad}(\mathrm{gram})$

BT= bobot tubuh ikan (gram)

Fekunditas telur $(\mathrm{N})$ dihitung sebagai jumlah telur yang terdapat dalam ovari pada setiap tingkat kematangan gonad yaitu :

$N=\frac{B G}{B S G} \times n$

Dimana :

$$
\begin{aligned}
& \mathrm{N}=\text { fekunditas } \\
& \mathrm{BG}=\text { berat gonad ikan } \\
& \mathrm{BSG}=\text { berat sampel gonad } \\
& \mathrm{N}=\text { jumlah telur dalam Bsg }
\end{aligned}
$$

Ukuran petama kali matang gonad (M) diduga dengan cara Spearman-Karber (Udupa, 1986). Rumus yang digunakan adalah sebagai berikut : 
$\mathrm{m}=(\mathrm{Xk}+\mathrm{X} / 2)-(\mathrm{X}, \Sigma \mathrm{pi})$

Kisaran ukuran panjang diduga dengan persamaan :

$\operatorname{antilog}[\mathrm{m} \pm 1,96 \sqrt{ }(\operatorname{var}(\mathrm{m}))]$

nilai $\operatorname{var}(\mathrm{m})=(\mathrm{X})^{2} \times \Sigma[($ pixqi $) /(\mathrm{ni}-1)]$

dimana :

$\mathrm{M}=$ ukuran pertama kali matang gonad (anti log dari $\mathrm{m}$ )

$\mathrm{m}=$ log panjang ikan pada kematangan gonad yang pertama

$\mathrm{Xk}=\log$ nilai tengah kelas panjang pada ikan $100 \%$ matang gonad

$\mathrm{X}=$ pertambahan log panjang nilai tengah kelas

$\mathrm{pi}=\mathrm{ri} / \mathrm{ni}=$ perbandingan jumlah ikan yang matang gonad pada tiap kelas panjang

$r i=$ jumlah ikan yang matang gonad pada kelas ke-i

$n i=$ jumlah contoh ikan pada kelas ke-i dan qi=1-pi

Isi saluran pencernaan dievaluasi dengan menggunakan indeks bagian terbesar (index of preponderance) (Natarajan dan Jhingran, 1961 dalam Effendie, 1979):

$$
I i=\frac{V i \times O i}{\sum(V i x O i)} x 100 \text {. }
$$

\section{Keterangan:}

$\mathrm{Ii}=$ Indeks bagian terbesar (index of preponderance)

$\mathrm{Vi}=$ Persentase volume satu macam makanan

Oi $=$ Persentase frekuensi satu macam makanan

Gambar 1. Lokasi penelitian di Danau Batur Bali.

Picture 1. The study sites in Lake Batur Bali.

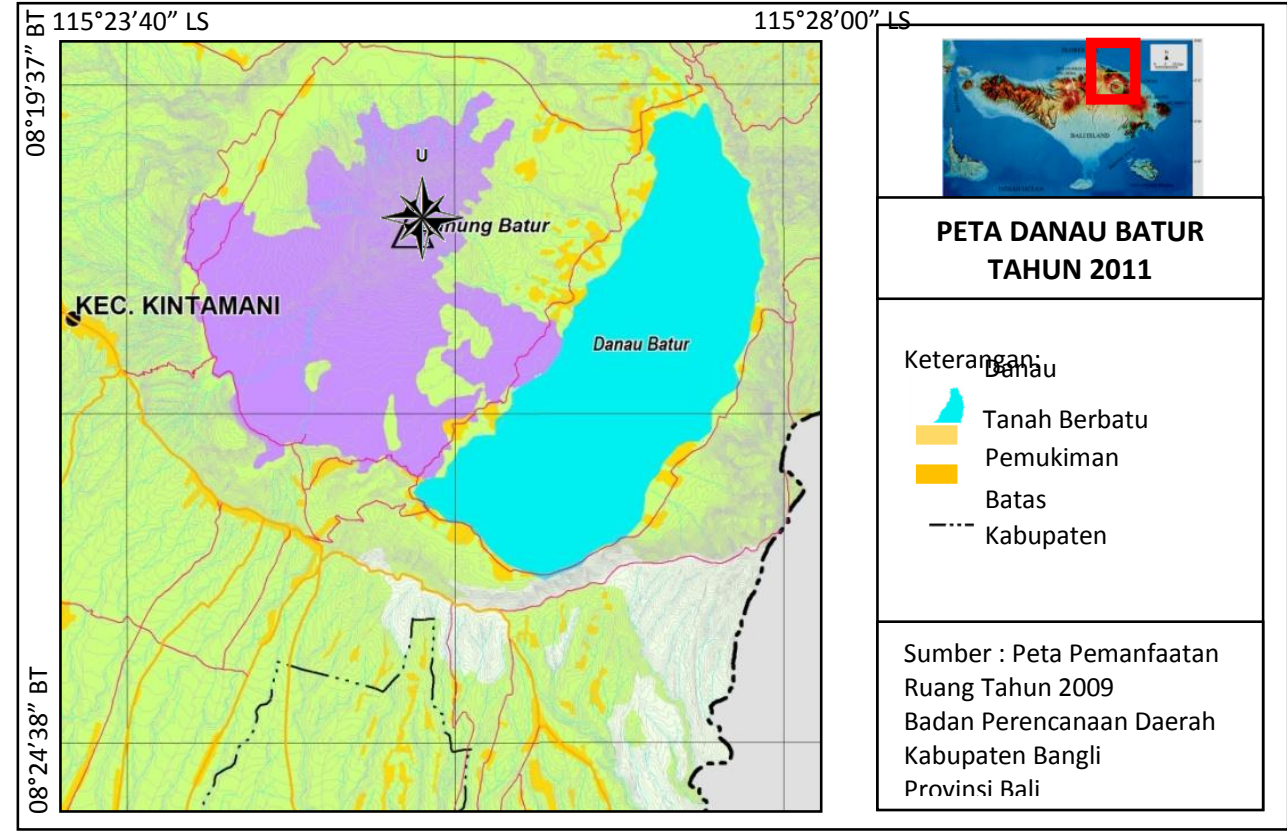


Tabel 1. Parameter kualitas air

Table 1. Water quality parameter

\begin{tabular}{|c|c|c|c|c|}
\hline $\begin{array}{l}\text { No } \\
\text { (No) }\end{array}$ & $\begin{array}{l}\text { Parameter } \\
\text { (Parameters) }\end{array}$ & $\begin{array}{c}\text { Satuan } \\
\text { (unit) }\end{array}$ & $\begin{array}{l}\text { Metode } \\
\text { (Methods) }\end{array}$ & $\begin{array}{l}\text { Alat } \\
\text { (Instruments/tools)) }\end{array}$ \\
\hline 1 & Suhu air & ${ }^{\circ} \mathrm{C}$ & In situ & Termometer air raksa \\
\hline 2 & Kedalaman & Meter & In situ & Depth Sounder \\
\hline 3 & Substrat dasar & ---- & In situ & Ekman grab \\
\hline 4 & $\mathrm{PH}$ air & unit & In situ & $\mathrm{pH}$ Indikator \\
\hline 5 & $\mathrm{O}_{2}$-terlarut & $\mathrm{mg} / \mathrm{L}$ & In situ & DO Meter \\
\hline 6 & TSS & $\mathrm{mg} / \mathrm{L}$ & & \\
\hline 7 & Total Nitrogen & $\mathrm{mg} / \mathrm{L}$ & Spektrofotometeri & Spektrofotometer \\
\hline 8 & Total Fosfor & $\mu g / L$ & Spektrofotometeri & Spektrofotometer \\
\hline 9 & Khlorofil-a & $\mu \mathrm{g} / \mathrm{L}$ & Kalorimetrik & Spektrofotometer \\
\hline
\end{tabular}

\section{HASIL DAN BAHASAN}

\section{Karakteristik Habitat}

Hasil pengukuran rata-rata beberapa parameter kualitas air di Danau Batur dapat dilihat pada tabel 2. Rata-rata suhu perairan di enam stasiun pengamatan adalah $(23,8 \pm 0,5)^{\circ} \mathrm{C}$. Nilai suhu dan fluktuasi yang kecil menunjukkan bahwa suhu perairan Danau Batur masih ideal untuk mendukung kehidupan organisme air (Pescod, 1973). Nilai rata-rata DO di Danau Batur yaitu $6,5 \pm 0,8 \mathrm{mg} / \mathrm{L}$ sangat layak untuk mendukung kehidupan ikan. NTAC (1968) menyatakan bahwa agar kehidupan ikan dapat hidup layak diperlukan kandungan oksigen terlarut minimal 4 $\mathrm{mg} / \mathrm{liter}$. Rata-rata $\mathrm{pH}$ perairan Danau Batur termasuk alkalis yaitu $8,6 \pm 0,1$. Nilai ini sedikit lebih tinggi dari kisaran nilai yang di sarankan menurut Swingle (1963) bahwa perairan yang ideal untuk mendukung kehidupan ikan dan organisme air sebagai makanan ikan adalah perairan yang mempunyai $\mathrm{pH}$ berkisar antara 6,5 sampai 8,5. Dilihat secara keseluruhan nilai parameter kualitas perairan di Danau Batur dapat dikatakan masih ideal untuk mendukung kehidupan ikan khususnya Nila.

Hasil analisis terhadap beberapa parameter kualitas air dengan menggunakan Principal Component and Classification Analysis (PCA) menunjukkan bahwa terdapat tiga pengelompokan stasiun yaitu kelompok I terdiri dari Toya Bungkah, Buahan dan Songan, Kelompok II yaitu Pura Jati dan Trunyan serta Kelompok III yaitu daerah tengah danau. Hal ini sesuai dengan kondisi habitat yang ada di lapangan dimana kelompok I merupakan wilayah yang memiliki daerah litoral yang cukup luas dan landai serta bersubstrat lumpur. Pada tiga stasiun tersebut juga banyak pemanfaatan lahan yang terjadi seperti aktifitas pemukiman, perkebunan, pariwisata, karamba jaring apung dan banyak terdapat tumbuhan air. Sedangkan kelompok II merupakan wilayah berbatu batu dengan kemiringan yang cukup terjal serta memiliki daerah litoral yang relatif sempit. Wilayah yang memiliki daerah litoral yang luas cenderung memiliki tingkat kesuburan yang lebih tinggi. Hal ini dikarenakan interaksi antara perairan dengan lahan yang ada membuat pasokan unsur hara ke perairan juga semakin meningkat sehingga kesuburan perairannya juga tinggi.

\section{Parameter Populasi Ikan Nila}

Hasil analisis terhadap parameter populasi ikan nila melalui sebaran frekuensi hasil tangkapan bulanan dengan memakai paket program FISAT (Gambar 3) memperlihatkan bahwa model pertumbuhan ikan nila di Danau Batur mengikuti persamaan von Bertalanffy sebagai berikut $\mathrm{Lt}=41,45^{*}(1-\exp (-0,52 *(\mathrm{t}-(-0,2867)))$. Artinya ikan nila di Danau ini mampu tumbuh 
hingga mencapai ukuran $41,45 \mathrm{~cm}$ dengan laju pertumbuhan $(\mathrm{K})$ sebesar 0,52 per tahun. Nilai $\mathrm{K}$ adalah suatu kurvatur yang menunjukkan seberapa cepat suatu jenis ikan dapat tumbuh hingga mencapai panjang infinitifnya (Sparre and Venema, 1999).

Berdasarkan model pertumbuhan diatas diperoleh nilai konstanta mortalitas alami (M) sebesar 0,9588 per tahun, konstata mortalitas penangkapan (F) sebesar 1,1014 per tahun, mortalitas total (Z) sebesar 2,06 per tahun dan laju eksploitasi stok (E) ikan nila ada sebesar 0,5347. Gulland (1983) menyatakan bahwa bila nilai optimum laju penangkapan (F) dari stok ikan yang dieksploitasi $\left(\mathrm{F}_{\mathrm{opt}}\right)$ sebanding dengan mortalitas alaminya $(\mathrm{M})$ maka laju eksploitasi optimum $\left(\mathrm{E}_{\mathrm{opt}}\right)$ adalah sebesar 0,5. Berdasarkan dari pernyataan tersebut, nilai laju eksploitasi ikan nila di Danau Batur sudah melebihi nilai optimumnya, artinya penangkapan ikan nila di Danau Batur telah melebihi nilai optimal (over fishing). Ukuran laju eksploitasi atau laju penangkapan terhadap ikan nila di Danau Batur ini, meskipun telah melebihi nilai optimum tidaklah menjadi masalah karena populasi jenis ikan nila di danau ini cukup melimpah, menurut informasi dari Dinas Perikanan setempat setiap tahun selalu dilakukan penebaran benih ikan, terutama ikan nila (lainnya adalah sedikit ikan mas dan tawes).

Hasil analisis program FISAT lebih lanjut terhadap pola rekruitmen (Gambar 4) menunjukkan bahwa ikan nila di Danau Batur dapat memijah dua kali dalam setahun. Puncakpuncak pemijahan ikan nila tersebut diperkirakan terjadi antara bulan-bulan Maret dan Juli dengan pemijahannya di alam tidak dilakukan sekali secara serentak, melainkan beberapa kali dan waktu yang berbeda pula.

\section{Aspek Biologi Reproduksi}

Nilai Indeks Kematangan Gonad (IKG) akan semakin meningkat nilainya dan mencapai maksimum pada saat terjadi pemijahan dan akan menurun secara bertahap dengan berakhirnya musim pemijahan. Cholik (2005) menyatakan bahwa sifat pemijahan ikan nila dapat dilihat dari nilai IKG nya yaitu jika IKG $<20 \%$ maka ikan tersebut memijah sepanjang tahun sedangkan jika nilai IKG > 20\% maka ikan tersebut memijah per musim.

Jenis ikan nila (Oreochromis niloticus) yang dominan tertangkap oleh nelayan di Danau Batur mempunyai indeks kematangan gonad (IKG) berkisar antara 0,4 - 6,2\% dengan fekunditas 232 - 968 butir dengan ukuran diameter telur berkisar antara 1-2,7 mm. Sesuai dengan pernyataan Cholik (2005) maka ikan Nila di Danau Batur termasuk ikan yang memijah sepanjang tahun. Menurut Ghufran (2011), selain dikenal sebagai ikan "tukang kawin" nila memiliki kemampuan melakukan kemampuan membuahkan yang sangat tinggi. Jarang sekali ada telur yang gagal terbuahi. Hal ini lah yang mengakibatkan populasi ikan Nila di Danau Batur sangat mendominasi.

Ukuran pertama kali matang gonad berdasarkan hasil analisa pada survei pertama sampai survei terakhir mempunyai ukuran antara $17,559-20,408 \mathrm{~cm}$.

\section{Makanan Alami (food habit)}

Berdasarkan pola kebiasaan pakannya, jenis ikan dapat dikelompokkan dalam 3 kelompok (Yanes-Arancibia, Linares dan Day , 1980), antara lain: yaitu Konsumen tingkat pertama, termasuk golongan pemakan plankton (fito-dan/atau zooplankton), pemakan detritus, dan pemakan vegetasi lainnya, serta omnivore (pemakan detritus, vegetasi lainnya dan organisme kecil); Konsumen tingkat dua, kelompok ini didominasi oleh ikan karnivora, dimana kelompok ikan ini sedikit mengkonsumsi vegetasi dan detritus, sedangkan pakan utamanya makro dan mikro benthos dan ikan kecil.; konsumen tingkat tiga, merupakan kelompok ikan yang sangat karnivorous dengan pakan utamanya makrozoobenthos dan ikan. Berdasarkan kriteria tersebut ikan Nila di Danau Batur termasuk ke dalam golongan konsumen tingkat pertama.

Berdasarkan strategi pemanfaatan pakan untuk masing-masing jenis dapat dikelompokkan dalam 2 tipe pemanfaatan (Hyatt,1979), antara lain; Spesialis, pengembangan spesialisasi dalam pemanfaatan pakan oleh kelompok ikan herbivore, bentik karnivora, 
planktivora dan piscivora banyak ditemui di daerah tropis dimana perairan daerah tersebut relative stabil dengan pola perubahan yang dapat diprediksi. Sehingga jenis ikan yang ada lebih selektif dalam memanfaatkan pakan yang tersedia.; Generalis, merupakan kelompok jenis ikan yang memanfaatkan pakan dengan range yang luas terhadap kualitas pakan. Umumnya kelompok ini banyak ditemui di perairan yang labil dan pola perubahannya tidak beraturan.

Giller (1984) menyatakan bahwa ikan yang mempunyai luas relung pakan yang luas atau kebiasaan pakan yang berpola generalis menunjukkan kesuksesan keberadaannya di suatu perairan, dan terjadi kompetisi intraspesifik, maka organisme tersebut cederung meningkatkan luas relungnya. Pada Danau Batur jenis ikan yang mempunyai pola generalis yaitu ikan Nila (Oreochromis niloticus) sehingga ikan ini cenderung menjadi yang paling dominan di Danau Batur. Selain hal tersebut, kurangnya populasi predator dan kompetitor ikan nila di alam juga mengakibatkan dominannya hasil tangkapan Nila di Danau Batur

Jenis pakan alami yang terdapat pada usus ikan Nila (Gambar 5) yaitu terdiri dari fitoplankton sebagai makanan utama sebesar $27 \%$, serasah atau detritus sebagai makanan tambahan (23\%) serta tumbuhan air sebagai makanan pelengkapnya (20\%). Pada nila dewasa memiliki kemampuan mengumpulkan makanan di perairan dengan bantuan mucus (lendir) di dalam mulutnya sehingga makanan tersebut menggumpal sehingga tidak mudah keluar (Ghufran, 2010). Hal ini sesuai dengan hasil pengamatan dimana fitoplankton yang di dapatkan biasanya berupa gumpalan-gumpalan. Jenis fitoplankton yang dominan didapat yaitu Synedra dan Fragillaria yang merupakan genus dari ordo Bacilariophyceae. Berdasarkan hasil pengukuran secara umum menunjukan bahwa panjang usus ikan nila lebih besar dibandingkan dengan panjang tubuhnya. Hal ini dikarenakan agar luas penampang usus tersebut juga semakin besar sehingga penyerapan sari - sari makanan menjadi lebih maksimal. Berdasarkan perbandingan tersebut maka ikan nila termasuk dalam jenis ikan herbivor mengarah ke omnivor yang memiliki usus panjang dan berkelit serta dinding usus yang relatif tipis.

Tabel 2. Nilai rata-rata parameter kualitas air di Danau Batur

Table 2. The average value of water quality parameter in Batur Lake

\begin{tabular}{|c|c|c|c|c|c|c|c|c|}
\hline No. & Stasiun & $\begin{array}{c}\text { Suhu } \\
\text { Air }\left({ }^{\circ}\right. \\
\text { C) }\end{array}$ & $\begin{array}{c}\mathrm{DO} \\
(\mathrm{mg} / \mathrm{l})\end{array}$ & $\mathrm{pH}$ & $\begin{array}{c}\text { Chl-a } \\
(\mu \mathrm{g} / \mathrm{L})\end{array}$ & $\begin{array}{l}\text { Total P } \\
(\mathrm{mg} / \mathrm{L})\end{array}$ & $\begin{array}{l}\text { Total N } \\
(\mathrm{mg} / \mathrm{L})\end{array}$ & $\begin{array}{c}\text { TSS } \\
(\mathrm{mg} / \mathrm{L})\end{array}$ \\
\hline 1. & Songan & 24,0 & 5,28 & 8,6 & 7,79 & 0,225 & 0,886 & 6,0 \\
\hline 2. & Toya Bungkah & 24,0 & 7,01 & 8,5 & 7,90 & 0,198 & 0,756 & 6,0 \\
\hline 3. & Pura Jati & 24,5 & 7,24 & 8,5 & 8,24 & 0,138 & 1,228 & 8,0 \\
\hline 4. & Buahan & 23,5 & 6,3 & 8,5 & 7,79 & 0,216 & 0,878 & 7,5 \\
\hline 5. & Trunyan & 23,0 & 5,94 & 8,7 & 8,34 & 0,218 & 0,746 & 6,5 \\
\hline 6. & Tengah Danau & 24,0 & 7,35 & 8,7 & 10,29 & 0,184 & 0,880 & 9,5 \\
\hline
\end{tabular}

Gambar 2. Pengelompokan stasiun pengamatan berdasarkan karakteristik habitat di Danau Batur.

Picture 2. Grouping of research station based on characteristic habitat in Batur Lake. 

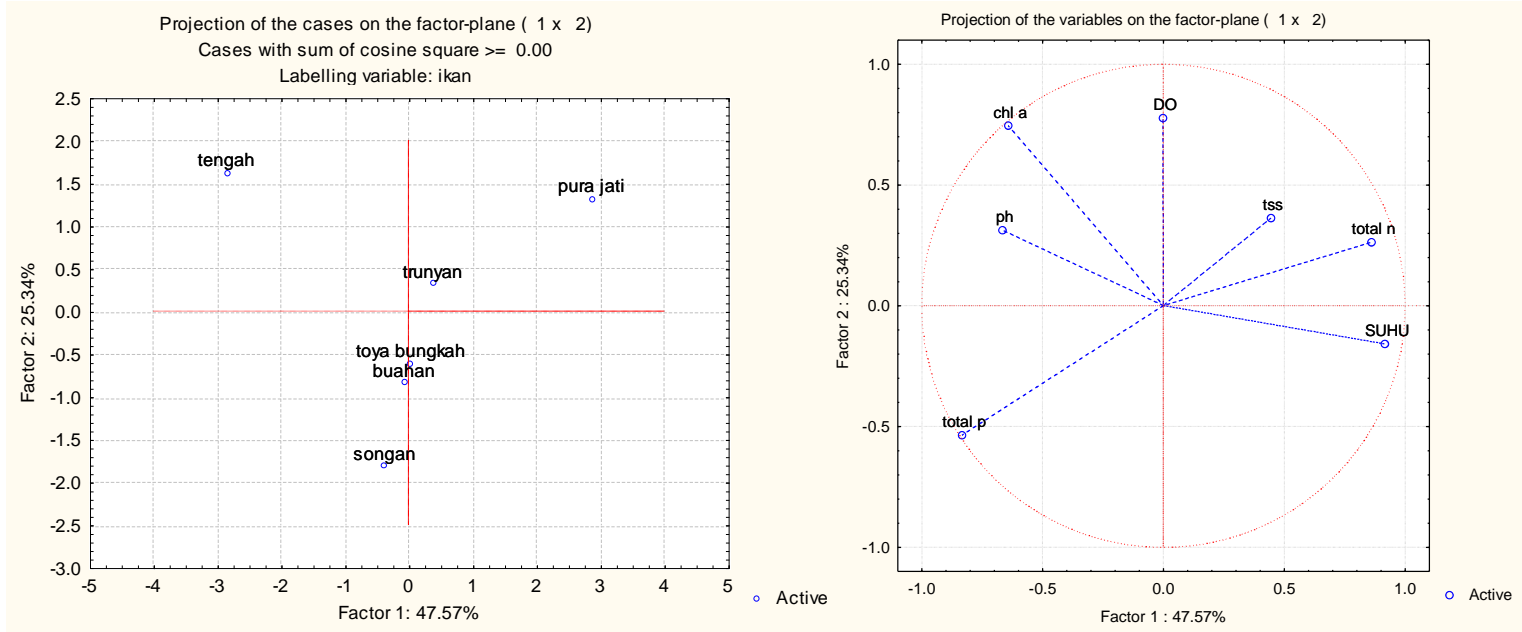

Gambar 3. Kurva pertumbuhan ikan nila (Oreochromis niloticus) di Danau Batur.

Picture 3. The growth curve of Tilapia (Oreochromis niloticus) in Batur Lake

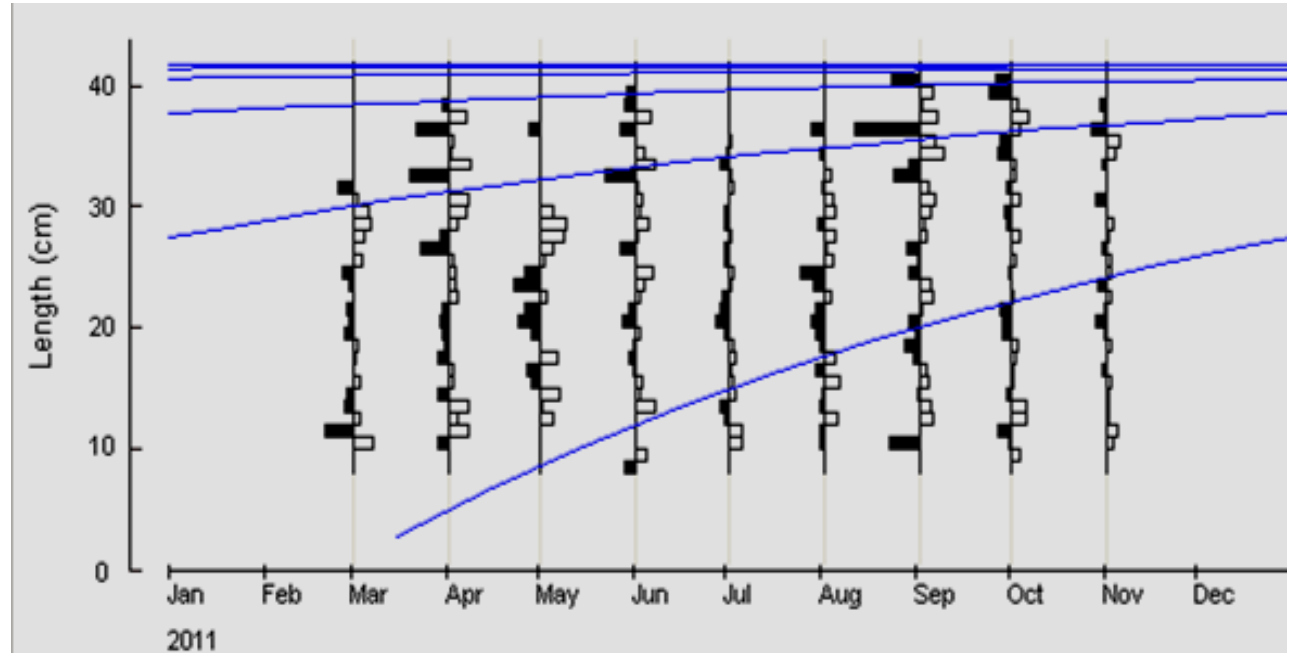

Gambar 4. Pola rekruitmen ikan nila di Danau Batur.

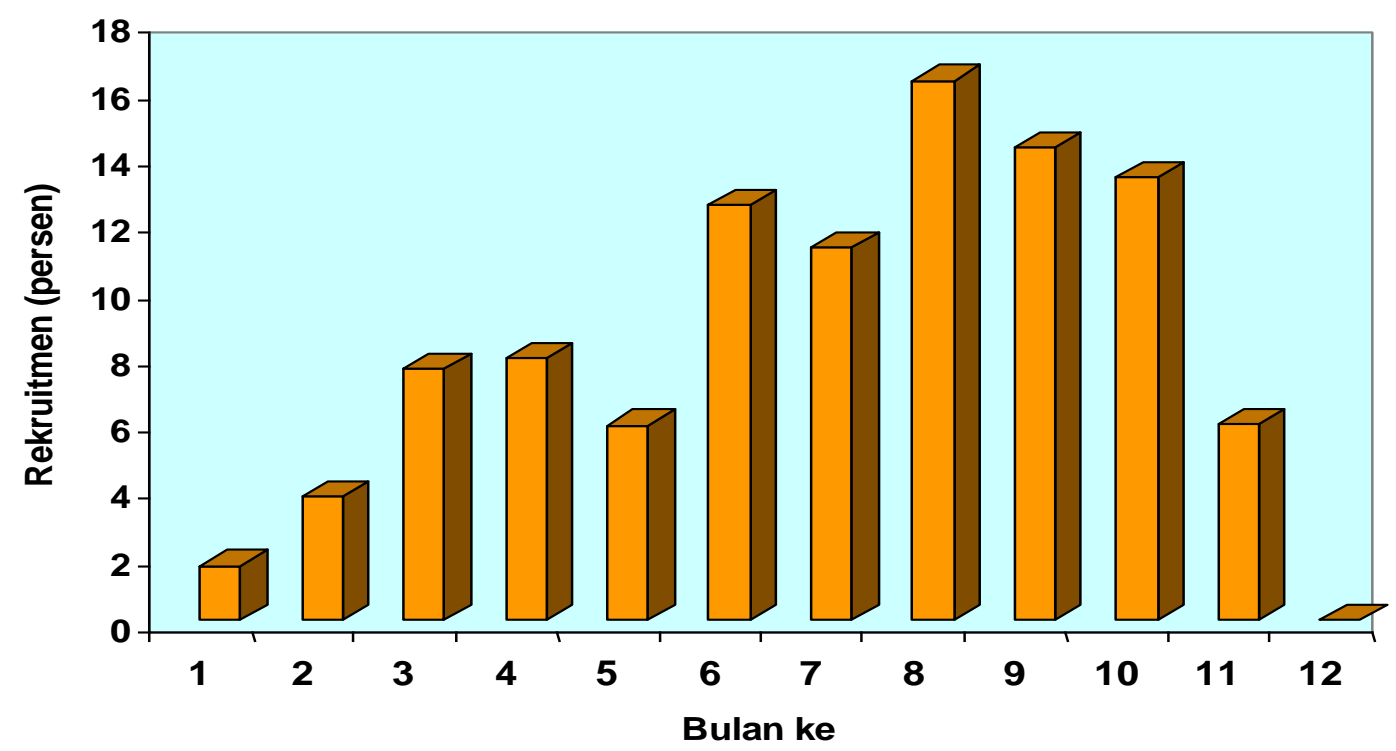


Gambar 5. Indeks Preponderance pada Ikan Nila (Oreochromis niloticus) di Danau Batur.

Picture 5. Indeks Preponderance of Tilapia (Oreochromis niloticus) in Batur Lake.

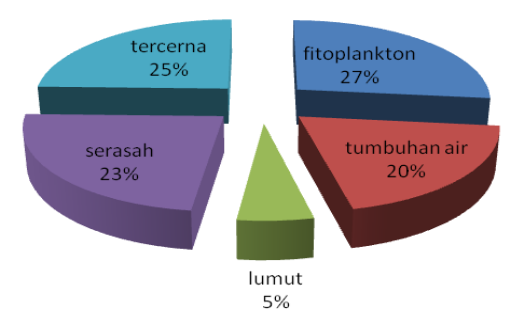

\section{KESIMPULAN}

1. Secara umum kondisi kualitas perairan di Danau Batur masih ideal untuk mendukung kehidupan ikan khususnya ikan Nila (Oreochromis niloticus).

2. Laju eksploitasi ikan Nila di Danau Batur telah melebihi nilai optimumnya artinya penangkapan ikan nila di Danau Batur telah melebihi nilai optimal (over fishing).

3. Ikan nila di Danau ini mampu tumbuh hingga mencapai ukuran $41,45 \mathrm{~cm}$ dengan laju pertumbuhan (K) sebesar 0,52 per tahun.

4. Ikan Nila di Danau Batur dapat memijah sepanjang tahun (IKG,20\%) dengan puncak pemijahan terjadi pada bulan Maret dan Juli.

5. Ukuran pertama kali ikan Nila di Danau Batur matang gonad antara 17,559 - 20,408 cm.

6. Ikan Nila di Danau Batur merupakan konsumen tingkat pertama dengan pola generalis dan termasuk ikan herbivore mengarah ke omnivore.

\section{DAFTAR PUSTAKA}

Anonimous. 2001. Peraturan Pemerintah Republik Indonesia No.82 Tahun 2001 Tentang pengelolaan kualitas air dan pengendalian pencemaran air. Jakarta. 38 p.

APHA. 1981. Standart Method for the Examination of Water and Wastewater, $15^{\text {th }}$ Edition. American Public Health Association, Washington, D.C. 1134 p.

Boyd, C.E. 1979. Water Quality in Warmwater fishponds. Auburn University, Depart. Of Fisheries and Alied Aquaculture. First Edition, Alabama, USA. 359 p.

Dinas Perikanan dan Kelautan Propinsi Bali. 2005. Identifikasi Potensi Sumberdaya Perairan Umum di Danau Batur. Denpasar, Bali. 78 p.

Effendie, M.I. 1979. Metode biologi perikanan. Yayasan Dewi Sri. Bogor. 112 hal.

Ghufran,M.H.K. 2010. Nikmat rasanya, nikmat untungnya-Pintar Budidaya Ikan di Tambak secara Intensif. Lily publisher. Yogyakarta. 262 hal.

Giler,P.S. 1984. community structure and the niche. Chapman and Hall, New York.

Gulland, J.A. 1983. Fish stock assessment. A manual of basic methods. Chichester, U.K. Wiley Interscience. FAO/Wiley series on food and agriculture, Vol. $1: 223 \mathrm{p}$.

Hyatt,K.D. 1979. Feeding strategy, p.71-119. In Hoar, W.S., D.J. Randall and J.R (eds.) Fish physiology: Bioenergitic and growth. Academic Press, London

Kottelat, M., J. A. Whitten, N. Kartikasari and S. Wiryoatmojo. 1993. Freshwater Fishes of Western Indonesia and Sulawesi. Periplus Edition and EMDI Project Indonesia, Jakarta. 221 p. 
Mizuno, T. 1978. Illustration of the Freshwater plankton of Japan. Hoikusha Publishing Japan.

Moreau, J. and S.S. De Silva. 1991. Predictive fish yield models for lakes and reservoirs of the Philippines, Sri Lanka and Thailand. FAO Fisheries Technical Paper (319). Food and Agriculture Organization of The United Nations, Rome. 42 p.

NTAC. 1968. Water Quality Criteria, FWPAC. Washington DC. 234 p.

Pauly, D. 1980. A selection of simple methods for the assessment of tropical fish stocks. FAO Fish. Circ. 729, 54 pp.

Pauly, D. 1983. Length-converted catch curves: a powerful tool for fisheries research in the tropics (part 1). ICLARM Fishbyte 2, 9-13.

Pauly, D. 1984. Some simple methods for the assessment of tropical fish stocks. FAO Fish. Tech. Pap. (234) : $52 \mathrm{p}$.

Pauly, D. and J.L. Munro. 1984. Once more on the comparison of growth in fish and invertebrates. ICLARM Fishbyte 2, 21.

Peraturan Pemerintah R.I. Nomor 82 Tahun 2001. Pengelolaan kualitas air dan pengendalian pencemaran air. $28 \mathrm{p}$.

Pescod, M.B. 1973. Investigation of rational and effluent and stream standards for tropical countries. AIT, Bangkok. 59 p.

Sparre, P. dan S.C. Venema. 1999. Introduksi pengkajian stok ikan tropis. Buku I, Manual. Pusat Penelitian dan Pengembangan Perikanan, Jakarta. 438 p.

Steel, R. G. D. and J. H. Torrie. 1981. Principles and Procedure of Statistic. Second Edition. Mic Graw Hill Book Company, Inc New York. 748 p.

Suryono, T., F. Sulawesty, S. Sunanisari, Cynthia H, Triyanto, G.S. Haryani, G.S. Aji, R.L. Toruan, T. Tarigan, G.P. Yoga, I. Ridwansyah, S. Nomosatryo, Y. Mardiati, E. Maulana dan Rosidah, 2008, Kajian Pengembangan Karakteristik Limnologis Perairan Darat di Indonesia, Laporan Teknis 2008, Program Penguatan Kelembagaan Iptek, Pusat Penelitian Limnologi LIPI, Cibinong.

Swingle, H.H. 1968. Standardization of chemical analysis for waters and pond muds. FAO Fisheries Report 44(4) : p. 397-406

Udupa, K. S. 1986. Statistical methods of estimating the size at first maturity in fishes. Fishbyte 4 (2) : 8-10. ICLARM, Metro Manila.

Wetzel, R. G. 1975. Limnology. W. B. Sauders Co. Philadelphia, Pennsylvania. 743 p.

Yanes-Arancibia, A., F.A. Linares and J.W. Day . 1980. fish community structure and function in terminus lagoon, a tropical estuary in the Southern Gulf Mexico. P.465-482. in Kennedy, V.S. (eds.) Estuarine perspective. Academic, Press, New York 